Artikel Penelitian

\title{
Hubungan Kebiasaan Merokok dengan Tekanan Darah pada Siswa SMK N 1 Padang
}

\author{
Aulia Fash Farabi ${ }^{1}$, Afriwardi ${ }^{2}$, Gusti Revilla ${ }^{3}$
}

\section{Abstrak}

Hipertensi dapat mengganggu fungsi organ lain terutama organ vital seperti jantung dan ginjal. Hipertensi tidak hanya menyerang di usia tua saja, tetapi juga remaja. Merokok merupakan salah satu faktor pencetus hipertensi. Tujuan penelitian ini adalah untuk mengetahui hubungan antara kebiasaan merokok dan tekanan darah pada siswa SMK N 1 Padang. Rancangan penelitian yang digunakan adalah penelitian analitik dengan desain cross-sectional. Sampel penelitian ini adalah 111 orang siswa kelas XI SMK N 1 Padang. Penilaian status merokok dengan menggunakan kuesioner Global Youth Tobacco Survey (GYTS) yang telah disadur dan digabungkan dengan indeks Brinkman dan penilaian tekanan darah dengan sphygmomanometer air raksa serta stetoskop. Hasil penelitian didapatkan siswa bukan perokok sebanyak 68 orang $(61,3 \%)$ dan perokok ringan sebanyak 43 orang $(38,7 \%)$. Ratarata tekanan darah sistolik siswa sebesar $112,57 \mathrm{mmHg}$ dan tekanan darah diastolik siswa sebesar 70,05 $\mathrm{mmHg}$. Didapatkan tekanan darah sistolik perokok ringan lebih rendah 2,1 $\mathrm{mmHg}$ dibandingkan bukan perokok dan tekanan diastolik perokok ringan lebih rendah $2,92 \mathrm{mmHg}$ dibandingkan bukan perokok. Hasil analisis data statistik kebiasaan merokok dengan tekanan darah sistolik didapatkan $p=0,15$. Hasil analisis data statistik kebiasaan merokok dengan tekanan darah disatolik didapatkan $p=0,078$. Sedangkan hasil analisis data statistik kebiasaan merokok dengan mean arterial pressure (MAP) didapatkan $p=0,094$, Simpulan penelitian ini menunjukan tidak terdapat hubungan kebiasaan merokok dengan tekanan darah sistolik, tekanan darah diastolik dan MAP

Kata kunci: kebiasaan merokok, tekanan darah sistolik, tekanan darah diastolik, MAP

\section{Abstract}

Hypertension can impair function of another organs especially the vital organs such heart and kidneys. Smoking cigarette is one of precipitating factors of hypertension. The objective of this study was to determine the correlation of smoking habit and blood pressure among student in SMKN 1 Padang. The research was an analytic study using by cross-sectional design. The sample was 111 students of grade XI SMKN 1 Padang divided by inclusion and exclusion criteria. The smoking status assessed using questionnaires of Global Youth Tobacco Survey (GYTS) which have been adapted and combined with Brinkman index and the assessment of blood pressure used mercury sphygmomanometer and stethoscope. This research found there are 68 students $(61,3 \%)$ were non-smoker and 43 students $(38,7 \%)$ were mild smoker. Mean systolic blood pressure is $112,57 \mathrm{mmHg}$ and mean diastolic blood pressure is $70,05 \mathrm{mmHg}$. There is $2,1 \mathrm{mmHg}$ difference in systolic blood pressure, lower in mild smoker than non-smoker and 2,92mmHg difference in diastolic blood pressure, lower in mild smoker than non-smoker. From statistical data analysis of cigarette smoking and systolic blood pressure obtained $p=0,15$. From the statistical data analysis of cigarette smoking and diastolic blood pressure obtained $p=0,078$. Whereas the statistical data analysis of cigarette smoking and mean arterial pressure (MAP) $p=0,094$. The conclusion is no correlation of smoking habit and systolic or diastolic blood pressure and MAP. Keywords: smoking habit, systolic blood pressure, diastolic blood pressure, MAP

Affiliasi penulis: 1. Prodi Profesi Dokter FK Unand (Fakultas Kedokteran Universitas Andalas Padang), 2. Bagian Fisiologi FK Unand, 3. Bagian Anatomi FK Unand
Korespondensi: Aulia Fash Farabi, email: abi.madden@gmail.com, Telp: +6281266239222 


\section{PENDAHULUAN}

Tekanan darah adalah tekanan yang ditimbulkan pada dinding arteri. Tekanan puncak terjadi saat ventrikel berkontraksi dan disebut tekanan sistolik. Tekanan diastolik adalah tekanan terendah yang terjadi saat jantung beristirahat. Tekanan darah seseorang dapat lebih atau kurang dari batasan normal. Jika melebihi nilai normal, orang tersebut menderita tekanan darah tinggi/hipertensi. Sebaliknya, jika kurang dari nilai normal, orang tersebut menderita tekanan darah rendah/hipotensi. ${ }^{1}$

Hipertensi adalah suatu keadaan ketika tekanan darah di pembuluh darah meningkat secara kronis. Hal tersebut dapat terjadi karena jantung bekerja lebih keras memompa darah untuk memenuhi kebutuhan oksigen dan nutrisi tubuh. Jika dibiarkan, penyakit ini dapat mengganggu fungsi organ-organ lain, terutama organ-organ vital seperti jantung dan ginjal. $^{2}$ Hipertensi tidak hanya menyerang di usia tua saja, tetapi remaja juga bisa mengalaminya. Hal ini terbukti antara tahun 1988 dan 1999, prehipertensi dan hipertensi diperkirakan meningkat secara nyata pada anak-anak dan remaja sebesar $2,3 \%$ dan $1 \%$. Hipertensi pada anak dikaitkan dengan hipertensi saat dewasa, faktor risiko kejadian penyakit jantung dan kematian ini juga dikaitkan terutama dengan hipertrofi ventrikel kiri, pada anak-anak dan dewasa. $^{3}$

Prevalensi hipertensi pada usia muda masih rendah, hal ini bisa saja menjadi masalah kesehatan yang serius karena akan mengakibatkan komplikasi yang berbahaya jika tidak terkendali dan tidak diupayakan pencegahan dini faktor-faktor risiko yang mempengaruhi kejadian hipertensi pada remaja. Pada remaja dan dewasa muda yang mengalami kenaikan tekanan darah ringan akan mempertinggi resiko hipertensi di kemudian hari. ${ }^{4}$

Di berbagai negara saat ini, prevalensi hipertensi meningkat sejalan dengan perubahan gaya hidup seperti merokok, obesitas, penurunan aktivitas fisik dan stress psikosial. Hipertensi sekarang ini sudah menjadi masalah kesehatan masyarakat dan akan menjadi masalah yang lebih besar jika tidak ditanggulangi sejak dini. ${ }^{5}$
Kebiasaan merokok dapat meningkatkan kemungkinan seseorang terserang beberapa penyakit seperti penyakit jantung, kanker dan Penyakit Paru Obstruktif Kronis (PPOK). Penelitian juga menemukan bahwa merokok dapat menurunkan fungsi kardiorespirasi tubuh. ${ }^{6}$ Rokok juga menyebabkan kematian pada lima juta penduduk dunia, dimana lima juta meninggal akibat penggunaan rokok secara langsung dan 500 ribu orang meninggal akibat terpapar asap rokok dari penggunanya. ${ }^{5}$

Merokok merupakan salah satu faktor yang dapat meningkatkan tekanan darah. $^{7}$ Kandungan rokok yang diketahui dapat meningkatkan tekanan darah salah satunya adalah nikotin yang bersifat simpatomimetik yang mengakibatkan peningkatan denyut jantung. Ketika terjadi vasokontriksi, denyut jantung akan meningkat sehingga terjadi peningkatan cardiac output. Proses ini menyebabkan tahanan perifer perifer meningkat dan mencegah pembuluh darah cidera akibat tingginya tekanan aliran darah yang ada. ${ }^{8,9}$

Hasil salah satu penelitian terhadap perokok didapatkan kejadian peningkatan tekanan darah sistolik sekitar $2 \mathrm{mmHg}$ berbeda antara perokok dan bukan perokok. ${ }^{10}$ Namun penelitian lain menemukan tekanan darah sistolik dan diastolik pada perokok justru lebih rendah dibandingkan dengan bukan perokok maupun orang yang telah berhenti merokok, yang pada perokok ringan justru tekanan darahnya lebih rendah $4 \mathrm{mmHg}$ dibandingkan bukan perokok, sementara pada perokok berat tekanan darahnya lebih rendah $2 \mathrm{mmHg}$ dibandingkan bukan perokok. ${ }^{11}$

Berdasarkan masalah yang ditemukan diatas, maka perlu dilakukan penelitian mengenai gambaran tekanan darah pada remaja di Indonesia, terutama antara yang merokok dan tidak merokok.

\section{METODE}

Rancangan penelitian yang digunakan adalah penelitian analitik dengan desain cross-sectional. Penelitian ini akan mendeskripsikan hubungan antara kebiasaan merokok dengan tekanan darah pada siswa SMKN 1 Padang. Penelitian ini dilakukan di bulan September 2014 di SMKN 1 Padang. 
Populasi dalam penelitian ini adalah seluruh siswa laki-laki kelas XI SMK N 1 Padang Tahun Ajaran 2014/2015. Sampel pada penelitian ini adalah bagian populasi yang memenuhi kriteria inklusi dan ekslusi. Kuesioner Global Youth Tobacco Survey digunakan untuk menilai kebiasaan merokok responden, sedangkan tekanan darah diukur dengan menggunakan sphygmomanometer air raksa dan stetoskop. Pemeriksaan tekanan darah dilakukan setelah responden mengisi kuesioner yang dibagikan. Data diolah secara manual kemudian status kebiasaan merokok dan tekanan darah disajikan dalam bentuk tabel distribusi frekuensi. Uji-t dilakukan untuk mengetahui hubungan antara variabel yang diteliti.

\section{HASIL}

Penelitian ini dilakukan terhadap 111 siswa laki-laki kelas XI SMKN 1 Padang. Informasi mengenai gambaran karakterikstik siswa kelas XI SMKN 1 Padang sebagai berikut.

Tabel 1. Distribusi siswa kelas XI SMKN 1 Padang

\begin{tabular}{ccc}
\hline Umur & Jumlah & $\%$ \\
\hline 14 tahun & 4 & 3,6 \\
15 tahun & 36 & 32,4 \\
16 tahun & 35 & 31,5 \\
17 tahun & 22 & 19,8 \\
18 tahun & 14 & 12,6 \\
\hline Total & $\mathbf{1 1 1}$ & $\mathbf{1 0 0}$ \\
\hline
\end{tabular}

Berdasarkan Tabel 1 dapat dilihat siswa terbanyak terdapat pada usia 15 tahun sebanyak 36 orang dan paling sedikit pada usia 14 tahun sebanyak 4 orang.

Tabel 2. Distribusi Indeks Brinkman Siswa Kelas XI SMKN 1 Padang

\begin{tabular}{ccc}
\hline Nilai Indeks Brinkmann & $\mathbf{n}$ & $\%$ \\
\hline 0 & 68 & 61,3 \\
$1-199$ & 43 & 38,7 \\
$200-600$ & 0 & 0 \\
$>600$ & 0 & 0 \\
\hline Jumlah & $\mathbf{1 1 1}$ & $\mathbf{1 0 0}$ \\
\hline
\end{tabular}

Berdasarkan Tabel 2, terdapat $68(61,3 \%)$ siswa dikategorikan memiliki indeks Brinkman 0. Hasil Tabel 2 didapatkan dari pengolahan data kuesioner GYTS dan diklasifikasikan menurut indeks Brinkman.

Tabel 3. Distribusi kebiasaan merokok siswa kelas XI SMKN 1 Padang menurut indeks Brinkman

\begin{tabular}{ccc}
\hline Kebiasaan Merokok & $\mathbf{n}$ & \% \\
\hline Bukan Perokok & 68 & 61,3 \\
Perokok Ringan & 43 & 38,7 \\
Perokok Sedang & 0 & 0 \\
Perokok Berat & 0 & 0 \\
\hline Total & $\mathbf{1 1 1}$ & $\mathbf{1 0 0}$ \\
\hline
\end{tabular}

Berdasarkan Tabel 3, sebanyak 68 orang dikategorikan bukan perokok dan 43 orang dikategorikan perokok ringan.

Tabel 4. Gambaran rata-rata tekanan darah siswa kelas XI SMKN 1 Padang

\begin{tabular}{ccc}
\hline Tekanan Darah & Rata-rata $(\mathbf{m m H g})$ & SD \\
\hline Sistolik & 112,57 & $\pm 10,35$ \\
Diastolik & 70,05 & $\pm 8,54$ \\
\hline
\end{tabular}

Berdasarkan Tabel 4, rata-rata tekanan darah sistolik siswa adalah $112,57 \mathrm{mmHg}(\mathrm{SD} \pm 10,35)$ dan tekanan darah diastolik siswa $70,05 \mathrm{mmHg}$ (SD $\pm 8,54)$.

Tabel 5. Distribusi gambaran tekanan darah sistolik siswa kelas XI SMKN 1 Padang

\begin{tabular}{ccc}
\hline Tekanan Darah Sistolik & $\mathbf{n}$ & $\%$ \\
\hline$<90 \mathrm{mmHg}$ & 0 & 0 \\
$90-119 \mathrm{mmHg}$ & 63 & 56,7 \\
$120-139 \mathrm{mmHg}$ & 48 & 43,2 \\
\hline Total & $\mathbf{1 1 1}$ & $\mathbf{1 0 0}$ \\
\hline
\end{tabular}

Berdasarkan Tabel 5, tekanan darah sistolik siswa terbanyak berada pada angka $90-119 \mathrm{mmHg}$ sebanyak 63 orang $(56,7 \%)$.

Informasi mengenai distribusi tekanan darah diastolik siswa kelas XI SMKN 1 Padang adalah sebagai berikut. 
Tabel 6. Distribusi gambaran tekanan darah diastolik siswa kelas XI SMKN 1 Padang

\begin{tabular}{ccc}
\hline Tekanan Darah Diastolik & $\mathbf{n}$ & $\%$ \\
\hline$<60 \mathrm{mmHg}$ & 6 & 5,4 \\
$60-79 \mathrm{mmHg}$ & 73 & 65,7 \\
$80-89 \mathrm{mmHg}$ & 31 & 27,9 \\
$90-99 \mathrm{mmHg}$ & 1 & 0,9 \\
\hline Total & $\mathbf{1 1 1}$ & $\mathbf{1 0 0}$ \\
\hline
\end{tabular}

Berdasarkan Tabel 6, tekanan darah diastolik siswa terbanyak pada angka $60-79 \mathrm{mmHg}$ sebanyak 73 orang $(65,7 \%)$.

Berdasarkan penelitian, diperoleh mengenai pengelompokan rata-rata tekanan darah sistolik dan diastolik siswa kelas XI SMKN 1 Padang berdasarkan kebiasaan merokok sebagai berikut

Tabel 7. Pengelompokan rata-rata tekanan darah sistolik, diastolik, dan Mean Arterial Pressure (MAP) siswa kelas XI SMKN 1 Padang berdasarkan kebiasaan merokok

\begin{tabular}{|c|c|c|c|c|}
\hline & \multicolumn{2}{|c|}{ Kebiasaan Merokok } & \multirow{2}{*}{$\begin{array}{l}\text { Hasil } \\
\text { Uji-t }\end{array}$} & \multirow[b]{2}{*}{$\mathbf{P}$} \\
\hline & $\begin{array}{c}\text { Bukan } \\
\text { Perokok }\end{array}$ & $\begin{array}{c}\text { Perokok } \\
\text { Ringan }\end{array}$ & & \\
\hline $\begin{array}{c}\text { Rata-rata } \\
\text { Tekanan Darah } \\
\text { Sistolik (mmHg) }\end{array}$ & $\begin{array}{c}113,38 \pm \\
10,31\end{array}$ & $\begin{array}{c}111,28 \pm \\
10,41\end{array}$ & 1,041 & 0,15 \\
\hline Rata-rata & & & & \\
\hline $\begin{array}{c}\text { Tekanan Darah } \\
\text { Diastolik } \\
(\mathrm{mmHg})\end{array}$ & $\begin{array}{c}71,18 \pm \\
7,64\end{array}$ & $\begin{array}{c}68,26 \pm \\
9,63\end{array}$ & 1,722 & 0,078 \\
\hline $\begin{array}{c}\text { Mean Arterial } \\
\text { Pressure }\end{array}$ & $\begin{array}{c}85,24 \pm \\
7,47\end{array}$ & $\begin{array}{c}82,60 \pm \\
8,87\end{array}$ & 1,691 & 0,094 \\
\hline
\end{tabular}

Analisis data diakukan dengan uji-t. Pada tekanan darah sistolik didapatkan hasil uji-t $=1,041$ dan $p=0,15$. Hal ini berarti tidak terdapat hubungan antara kebiasaan merokok dengan tekanan darah sistolik $(p>0,05)$. Pada tekanan darah diastolik didapatkan hasil uji-t $=1,722$ dan $p=0,078$. Hal ini berarti tidak terdapat hubungan antara kebiasaan merokok dengan tekanan darah diastolik $(p>0,05)$. Pada pengujian MAP antara perokok dan bukan perokok didapatkan hasil uji $t=1,691$ dan $p=0,094$. Hal ini berarti tidak terdapat hubungan antara kebiasaan merokok dengan MAP $(p>0,05)$.

\section{PEMBAHASAN}

Jumlah responden kategori bukan perokok sebanyak 68 orang $(61,3 \%)$ dan perokok ringan 43 orang $(38,7 \%)$. Hasil ini berbeda dengan penelitian Global Youth Tobacco Survey (GYTS) pada tahun 2009 yang dilakukan di Indonesia. Penelitian tersebut menunjukan perilaku merokok pada siswa usia 13-15 tahun sebesar 20,3\%. Dari data tersebut, untuk jenis kelamin laki-laki, jumlah perokok sebesar $41 \%{ }^{12}$

Perilaku merokok pada usia remaja dapat meningkatkan kemungkinan mengalami masalah kesehatan pada saat dewasa. Merokok pada usia muda akan menurunkan laju pertumbuhan paru dan penurunan kapasitas paru, penurunan kebugaran. Selain itu terjadi percepatan pembentukan lesi arterosklerotik yang akan memicu berbagai penyakit kardiovaskuler lainnya. ${ }^{13}$

Hasil penelitian menunjukan rata-rata tekanan darah sistolik sebesar $112,57 \mathrm{mmHg}$ dan tekanan darah diastolik sebesar $70,05 \mathrm{mmHg}$.Data penelitian menunjukan tekanan darah sistolik siswa terdapat pada rentang 90-119 mmHg sebanyak 63 orang yang tergolong dalam nilai normal menurut klasifikasi JNC 7. Ada 48 orang lainnya berada dalam rentang 120 $139 \mathrm{mmHg}$ yang digolongkan pre-hipertensi. Tekanan darah diastolik siswa terdapat dalam empat kategori menurut JNC 7 dan Mayoclinic (2014); <60 mmHg sebanyak 6 orang yang dikategorikan hipotensi, 60-79 $\mathrm{mmHg}$ sebanyak 73 orang yang dikategorikan normal, 80-89 $\mathrm{mmHg}$ sebanyak 31 orang yang dikategorikan pre-hipertensi, dan 90-99 mmHg sebanyak satu orang yang dikategorikan hipertensi. ${ }^{14}$

Hasil penelitian menunjukan rata-rata tekanan darah sistolik dan diastolik siswa dengan status perokok ringan lebih rendah dibandingkan siswa bukan perokok. Pada perokok ringan rata-rata tekanan darah sistolik sebesar $111,28 \mathrm{mmHg}$ dan tekanan darah diastolik sebesar $68,26 \mathrm{mmHg}$ sedangkan pada siswa bukan perokok, tekanan darah sistolik sebesar $113,38 \mathrm{mmHg}$ dan tekanan darah diastolik $71,18 \mathrm{mmHg}$. Data tekanan darah sistolik penelitian ini sesuai dengan penelitian Papathanasiou et al tahun 2012 yang dilakukan pada siswa berusia 
20-29 tahun yang menunjukan tekanan darah sistolik pada perokok lebih rendah dibandingkan dengan yang tidak merokok yaitu 124,3 mmHg berbanding 125,1 mmHg. ${ }^{15}$ MAP pada siswa bukan rokok adalah $85,24 \mathrm{mmHg}$ dan pada siswa perokok adalah 82,60 $\mathrm{mmHg}$. Hal ini berbeda dengan penelitian Peebles pada tahun 2013 yang mendapatkan nilai MAP untuk bukan perokok sebesar $79 \mathrm{mmHg}$ dan pada perokok sebesar $78 \mathrm{mmHg} .^{16}$

Rebound phenomenon dan proses adaptasi merupakan alasan tekanan darah pada perokok lebih rendah dibandingkan perokok. ${ }^{11}$ Nikotin, salah satu kandungan rokok, dapat memicu pelepasan nitrit oksida sintase (NOS) yang membantu kinerja baroreseptor untuk mempertahankan tekanan darah terutama melalui aktivitas umpan balik negative. ${ }^{17}$ Inhalasi karbon monoksida (CO), salah satu kandungan asap rokok, dalam jumlah yang rendah ( $\leq 250 p p m)$ dapat memicu efek relaksasi pembuluh darah. CO juga berperan sebagai penghambat vasokontriksi setelah terjadi blokade NO. ${ }^{18}$

Pada penelitian ini juga terdapat tekanan darah dengan kategori pre-hipertensi dan hipertensi. Hal tersebut dipengaruhi oleh respon tubuh seperti penurunan sensitivitas barorefleks, gangguan fungsi buffer arteri dan gangguan respon vasokontriksi pada perokok. ${ }^{19}$ Aktivitas fisik, nutrisi, alkohol dan stress juga mempengaruhi nilai tekanan darah seseorang. ${ }^{20}$

\section{KESIMPULAN}

Tidak ditemukan hubungan antara kebiasaan merokok dengan tekanan darah pada siswa SMKN 1 Padang.

\section{SARAN}

Menilai faktor selain kebiasaan merokok untuk dikaji hubungannya terhadap tekanan darah seperti kebiasaan olahraga, tingkat stres, dan asupan nutrisi, karena beberapa faktor tersebut juga dapat mempengaruhi hasil yang didapatkan.

Walaupun tidak ditemukan hubungan antara kebiasaan merokok terhadap tekanan darah pada penelitian ini, perlu diadakan kegiatan promotif dan pencegahan pada siswa sekolah menengah mengenai rokok dan bahaya yang ditimbulkan oleh rokok.

\section{DAFTAR PUSTAKA}

1. Palmer A. Tekanan darah tinggi. Jakarta: Erlangga; 2010.

2. Smeltzer SC, Bare, BG. Buku ajar keperawatan medikal bedah (terjemahan). Edisi ke-8 Vol.2. Jakarta: EGC; 2001.

3. Redwine KM, Daniels SR. Prehypertension in adolescents: risk and progression. The Journal of Clinical Hypertension. 2012;14(6):360-4.

4. Departemen Kesehatan Republik Indonesia. Hipertensi faktor resiko utama penyakit kardiovaskular. Pusat Komunikasi Publik. Sekretariat Jenderal Departemen Kesehatan; 2009.

5. World Health Organisation (WHO). A global brief on hypertension. Swiss: WHO; 2013.

6. HOYT GL. Cigarette smoking: nicotine, carbon monoxide, and the physiological effects on exercise responses. Sport Science Review. 2013; 21: 5-24.

7. USDHHS. How tobacco smoke causes disease: the biology and behavioral basis for smokingattributable disease: a report of the surgeon general. Rockville: USDHHS; 2010.

8. Smith DL, Fernhall Bo. Advanced cardiovascular exercise physiology. USA: Human Kinetics; 2011.

9. Omvik P. How smoking affects blood pressure. 1996. (diunduh 11 Juni 2014). Tersedia dari: URL: HYPERLINK:http://www.ncbi.nlm.nih.gov/pubmed/ $\underline{9162447 .}$.

10. Primatesta P. Falaschetti E. Gupta S. Marmot MG. Poulter NR. Association between smoking and blood pressure, AHA Journal. 2001;37:187-93. (diunduh 11 Juni 2014). Tersedia dari: URL: HYPERLINK:http://hyper. ahajournals.org/content/3 7/2/187.abstract.

11. Okubo Y. Miyamoto T. Suwazano Y. Kobayashi E. Nogawa K. An association between smoking habits and blood pressure in normotensive Japanese men. Journal of Human Hypertension. 2002;16;2: 91-96. (diunduh 11 Juni 2014). Tersedia dari: URL:HYPERLINK:http://www.nature.com/jhh/journ al/v16/n2/full/1001303a.html.

12. GYTS. Indonesia GYTS 2009 Factsheet Ages 1315. 2009. (diunduh 1 Oktober 2014). Tersedia dari: 
URL:HYPERLINK:http://www.searo.who.int/entity/n oncommunicable diseases/data/ino gyts fs 2009. pdf.

13. Center for Disease Control and Prevention (CDC). Preventing tobacco use among young people, a report of the surgeon general, Executive Summary. US: USDHHS; 1994.

14. USDHHS. JNC 7 Express. USA: NIH Publication; 2003.

15. Papathanasiou G, Georgakopoulus D, Papageorgiou E, Zerva E, Michalis L, Kalfakakou V, Evangelou A. Effect of smoking on heart rate at rest and during exercise, and on heart rate recovery, in young adults. Helenic J Cardiol. 2013; 54:168-77.

16. Peebles KC, Horsman H, Tzeng Y. The Influence of tobacco smoking on the relationship between pressure and flow in the middle cerebral artery in humans. Plos One. 2013;8.

17. Fouda MA. El-Gowelli HM. El-Gowilly SM. Rashed L. El-Mas MM. Impairment of nitric oxide synthase but not heme oxygenase accounts for baroreflex dysfunction caused by chronic nicotine in female rats. Plose One Journal. 2014;9:5.

18. Stec DE. Drummond HA. Vera T. Role of carbon monoxide in blood pressure regulation. Hypertension AHA. 2008;51:597-604.

19. Jee D. Park U. Hemodynamic response of young smokers to induction and intubation. Korean $\mathrm{J}$ Anesthesiol. 2006;50:14-8.

20. McKinley Heart Center. Factors that affect blood pressure. 2008 (diunduh 01 Oktober 2014). Tersedia dari: URL: HYPERLINK http://www. mckinley.illinois.edu/handouts/blood pressure fact ors.html. 